\title{
Job Satisfaction and Dissatisfaction as Outcomes of Psychological Contract: Evidence from the South African Workplace
}

\author{
David Isaac Ntimba*, Karel Frederick Lessing, Ilze Swarts \\ Tshwane University of Technology, Pretoria, South Africa \\ Email: ^david.ntimba@gmail.com, lessingkf@tut.ac.za, swartsi@tut.ac.za
}

How to cite this paper: Ntimba, D. I., Lessing, K. F., \& Swarts, I. (2021). Job Satisfaction and Dissatisfaction as Outcomes of Psychological Contract: Evidence from the South African Workplace. Journal of Human Resource and Sustainability Studies, 9, 484-502.

https://doi.org/10.4236/jhrss.2021.93031

Received: August 23, 2021

Accepted: September 19, 2021

Published: September 22, 2021

Copyright $\odot 2021$ by author(s) and Scientific Research Publishing Inc. This work is licensed under the Creative Commons Attribution International License (CC BY 4.0).

http://creativecommons.org/licenses/by/4.0/

\begin{abstract}
The study examined the influence that the psychological contract has on the job satisfaction and dissatisfaction of employees in the South African workplace. It also studied in detail, the effect that psychological contract breach and fulfilment have on the satisfaction of employees with regard to their work, fellow-employee, supervisor, and the as a whole organisation. The data for this study therefore, was collected through perusal of existing scientific articles/papers, published/unpublished dissertations and theses, text books and other relevant informative documents. This makes the study to be premised on theoretical and analytical methodology. This article therefore, reveals the destructive effects that psychological contract breach has on the operation of organisations in South Africa, which are also presented and discussed in detail. The article also reveals the costly effect that employees' job dissatisfaction has on organisations in terms of unplanned employee turnover. For the enhancement of psychological contract fulfilment, this article proposes strategies for organisations to adopt and implement, with an aim of improving employees' job satisfaction in the workplace and ultimately discouraging turover intentions among employees. This study therefore, plays a very important and significant role in terms of contributing to literature and better understanding of psychological contract in general, and the effects that psychological contract has on employees' job satisfaction and dissatisfaction in particular.
\end{abstract}

\section{Keywords}

Psychological Contract, Job Satisfaction, Breach, Fulfilment, Workplace, 
Oganisation

\section{Introduction}

The structure of this article consists of the following sections. Section 2 reviews the relevant literature that has been used in the study. Section 3 discusses the influence of psychological contract fulfillment and breach on employees' job satisfaction and dissatisfaction. Section 4 presents and discusses the determinants of employees' job satisfaction. Section 5 entails the discussion of the consequences of employees' job satisfaction in the workplace. Section 6 presents the recommended strategies that can be used to improve job satisfaction in organisations, while Section 7 provides the conclusion of the study. This study is one of the very few which addresses not only the impact of job satisfaction on employees, but also the effect that job dissatisfaction has on them in the workplace.

The biggest challenge that organisations seem to be faced with each day, is to ensure that their employees are satisfied in the workplace in order to enhance their production and keep their organisations going. Unfortunately, this is not always an easy task as employees' behaviour is influenced by many factors which organisations have to identify and manage in the workplace. The psychological contract therefore, has been reported by a number of researchers as having a significant impact on employees' job satisfaction (Collins \& Beauregards, 2020; Varma \& Chavan, 2020), hence it has been identified as a construct of interest for the study.

As already indicated, the aim of this study was to investigate if the psychological contract has any influence on employees' job satisfaction and dissatisfaction in the workplace, in order to gain relevant information and knowledge that can be used for the management of this construct in organisations. The psychological contract is a concept that can be traced back to Rousseau's work in 1989. According to this researcher, the concept of psychological contract is based on an individual's belief that mutual obligations exist between individuals and their employers, which each party will be expected to fulfil when the time comes (Rousseau \& Tijoriwala, 1998).

In order to provide a clear understanding of the concept, researchers of organisational behaviour have adopted the psychological contract as a theoretical foundation for the interpretation of the relationship between employees and employers in organisations. According to the psychological theory, employees hold a set of implicit expectations about what they feel obligated to provide to their employer such as productivity, and what their employer is obligated to provide them such as salary, career opportunities, safety, etc (Morf, Arnold, \& Staffelbach, 2014). This notion is supported by Griep and Vantilborgh (2018) who confirm that, in a psychological contract relationship employees believe that they have an implied contract with their employer as they regard their em- 
ployer as having promised to provide for their economic and materialistic needs in return for the employees' contribution to the organisation. According to Zacher and Rudolph (2021), the psychological contract serves as an encouragement for employees in organisations to hold on to positive expectations rather than the limitations that exist in organisations. Herrera and Las Heras-Rosas (2021) reveal that a positive connection has been found between the psychological contract and organisational commitment, especially where the terms of the contract have been fulfilled. This obviously means that, where the obligations and terms of the psychological contract have been met, the connection will be a positive one, while the opposite will also be true, where the psychological contract has been breached.

Employees' job satisfaction on the other hand, should be understood as an employee's actual satisfaction with the work and the immediate supervisor in the workplace (Janssen, 2001; Giauque et al., 2012; Ramoo et al., 2013; Yousef, 2017). The significance of satisfied employees rests in the fact that, when employees are satisfied in the workplace, they feel encouraged and motivated to continue working in their organisation and continue to tirelessly contribute to their organisation's effectiveness (Van der Walt et al., 2016). According to Othman, Mokhtar and Asaad (2017), job satisfaction or employee satisfaction has been found to be one of the most important predictors of any success in work organisations. Silitonga et al. (2020) supports this notion and further adds that job satisfaction influences organisational commitment in the work place, which obviously results in increased eagerness amongst employees to achieve organisational goals. Vuong et al. (2021: p. 204) re-iterates this notion and further adds that when employees are satisfied in the workplace, they will "always stand shoulder to shoulder with the organisation even in times of absolute difficulty". The opposite is also true that when employees experience any form of dissatisfaction especially relating to their work in the workplace, they tend to engage in certain behaviours that may have destructive consequences to organisations in terms of decreased production and/or resignations (Collins \& Beauregard, 2020; Danial \& Nasir, 2020; Morsch, Van Dijk, \& Kodden, 2020; Varma \& Chavan, 2020). Hence it is of utmost importance that organisations remain alert and prepared to take immediate corrective action, should any employee behaviour appear suspicious.

It is based on this background that the impact that the psychological contract has on employees' job satisfaction and dissatisfaction had to be examined, in order to obtain the required relevant information and knowledge that would assist management in work organisations to be able to monitor, control and manage the effects of the psychological contract in the workplace. This article therefore, has focused its review on available literature pertaining to: The psychological contract in the workplace; Impact of psychological contract fulfilment and breach on employees' job satisfaction and dis-satisfaction; Determinants of employees' job satisfaction; Consequences of employees' job dissatisfaction; Rec- 
ommended strategies of improving job satisfaction in organisations.

This article has been written on the basis of secondary data, obtained from scientific articles/papers, published/unpublished dissertations and theses, text books and other relevant informative documents.

\section{Literature Review}

\subsection{The Psychological Contract in the Workplace}

The term psychological contract was first used by Rousseau in her study in 1989. The author initially defined the psychological contract as employees' beliefs that there is a mutual obligation that exists between them and their organisations (Rousseau, 1995). This concept was later redefined by Rousseau and Tijoriwala (1998) as an individual's belief that mutual obligations exist between individuals and their employers, which each party will be expected to fulfil when the time comes in the workplace. Subsequent to the study of Rousseau and Tijoriwala (1998), numerous studies on the concept of psychological contracts followed, which resulted in new information and a development of a psychological theory which states that employees hold a set of implicit expectations about what they feel obligated to provide to their employer such as productivity, and what their employer is obligated to provide them such as salary, career opportunities, safety, etc (Morf, Arnold, \& Staffelbach, 2014). Although a number of researchers conducted studies on the psychological contract concept and came up with their own definitions, of significance in all the definitions of different researchers and authors, is the similarity in stating that the psychological contract is based on belief of an existence of obligations between an employee and the employer to keep their promises regarding any matter of individual interest in the workplace (Tekleab et al., 2020; Zacher \& Rudolph, 2021; Herrera \& Las Heras-Rosas, 2021).

Psychological contracts serve two vital roles, namely, to define and describe the employment relationship, and to manage the mutual expectations in the relationship. Psychological contracts also provide a functional framework according to which the open process of employees' expectations can be managed (Dhanpat \& Parumasur, 2014). The benefit of the psychological contract in workplace relationships can also be seen in the fact that it provides an "understanding of employment relationships, employee attitudes and behaviours" (Tekleab et al., 2020: p. 1). Where the psychological contract is properly handled and manged, it can be of benefit to organisations as it can encourage and motivate employees to contribute to the achievement of all expected positive organisational outcomes and goals (Dhanpat \& Parumasur, 2014; Tekleab et al., 2020; Liu, 2019; Zacher \& Rudolph, 2021).

There are two types of psychological contracts known as relational and transactional contracts that are popularly and commonly found in the workplace (Dhanpat \& Parumasur, 2014; Griep \& Vantilborgh, 2018). Relational contracts are characterised by elements of trust, respect and loyalty that develop over a period of time (Persson \& Wasieleski, 2015; Herrera \& Las Heras-Rosas, 2021; 
Cregan et al., 2021). Transactional contracts on the other hand are always characterised by their short-term focus on economic and materialistic factors such as fair remuneration, career advancement opportunities and job security (Herrera \& Las Heras-Rosas, 2021; Cregan et al., 2021). De Clercq, Azeem and Haq (2021) and Phuong and Takahashi (2021) concur with these authors' version of the relational and transactional contracts, but add that the relational contract contains relational obligations and evokes long-term expectations, while the transactional contract is characterised by transactional obligations which evolve around short-term expectations. An earlier study by Dabos and Rousseau (2004) further identified another type of psychological contract in 1995 which up to this far has not been commonly popular in the workplace, which they referred to as the balanced contract. This type of psychological contract was later referred to as hybrid contract because it was found to be a combination of both relational and transactional contracts (De Clercq, Azeem, \& Haq, 2021).

\subsection{Job Satisfaction and Dissatisfaction in Work Organisations}

The concept of job satisfaction was first used by Elton Mayo (calling it work satisfaction) at the Western Electric company Hawthorne factory in Chicago, during the late 1920's and early 1930's to describe employees' emotions which could affect their work behaviour (Djoemadi et al., 2019). There seems to be no uniform definition of job satisfaction, work satisfaction or employee satisfaction, as interchangeably referred to in the literature. However, numerous definitions of job satisfaction have been provided by various researchers and authors, with some similarities pertaining to satisfaction with employees' jobs in the workplace (Sowmya \& Panchanatham, 2011; Voon et al., 2011; Parvin \& Kabir, 2011; Sageer et al., 2012; Giauque et al., 2012; Ramoo et al., 2013; Yousef, 2017). However, the definition that stands out as being the most accurate is provided by Saman (2020:186), where he says job satisfaction should be understood as "the attitude of an employee either happy or not happy about rewards that come by, the work that is associated with his own, with his supervisors, fellow employees, as well as environmental work". Two earlier studies which were conducted by Dabos and Rousseau (2004) and later by Dhanpat and Parumasur (2014) have found that employees who are satisfied with their work will always want to reciprocate the positive actions of their employers in terms of increased productivity, positive organisational expectations, affective commitment and intention to remain in the organisation.

Conversely, job dissatisfaction, which is obviously the opposite of job satisfaction is defined by Nwobia and Aljohani (2017: p. 137) as "an unpleasant or negative, stress-related emotional state resulting to a re-appraisal of one's job or job experiences". Ramlawati et al. (2021) reveal that job dissatisfaction occurs when an employee's expectations are not met by his current job and begins to have thoughts of leaving his job, believing that by leaving his job he will get another job that will provide better job satisfaction. Two studies which were conducted 
by Maimane et al. (2018) and Liu (2019) found that employees who are dissatisfied in the workplace behave negatively to an extent that they would not hesitate to engage in negative behaviours such as reducing their performance efforts and withdrawing their organisational commitment, which oviously negatively affect production in organisations. A subsequent study which is one of many others, which was conducted by Ntimba (2019) has found that employees start to think about leaving their organisation when they feel dissatisfied about their work and are convinced that it would be worthless to continue working for an organisation in which they are not happy.

\section{Influence of Psychological Contract Fulfilment and Breach on Employees' Job Satisfaction and Dissatisfaction}

Psychological contract fulfilment take place when employees have a strong perception and conviction that their employers have met the terms of their implied contract called psychological contract (Lambert, Edwards, \& Cable, 2003; Liu, 2019). When employees feel that the terms of their psychological contract have been fulfilled by their employers, they become happy and want to reciprocate the positive action, by loyalty and commitment which result in higher production in organisations (Liu, 2019; Zacher \& Rudolph, 2021). Employees will always reciprocate the positive actions of their employers in terms of increased productivity, positive organisational expectations, affective commitment and intention to remain in the organisation (Dabos \& Rousseau, 2004; Dhanpat \& Parumasur, 2014). This view is supported by Griep and Vantilborgh (2018) who further state that employees always experience a feeling of indebtedness where they perceive the employer to have met all the psychological contract obligations. The result is that they too will want to reciprocate such positive behaviour by fulfilling their own obligations as expected in terms of their psychological contract.

Employees' perception of fulfilment of their psychological contract puts them in a state of satisfaction about their work and even about the organisation itself. The job satisfaction arising from psychological contract fulfilment leads to organisational outcomes such as, among others, organisational commitment, organisational citizenship behaviour and innovative behaviour, which are obviously beneficial to the survival of work organisations (Aggarwal \& Bhargava, 2009; Tekleab et al., 2020; Sudiarta, 2021). The impact of psychological contract fulfilment on job satisfaction is displayed on route (1) of Figure 1. The positive organisational outcomes that are brought about by the prevalence of job satisfaction in the workplace are also reflected. Also reflected in Figure 1, is the impact that psychological contract breach has on the job dissatisfaction of employees in the workplace. The negative organisational outcomes that are brought about by the prevalence of job dissatisfaction in the workplace are also reflected in Figure 1.

On the other hand, psychological contract breach refers to an awareness that one or more obligations have not been fulfilled by the other party, which triggers an emotional experience that results from the awareness that the other party has 


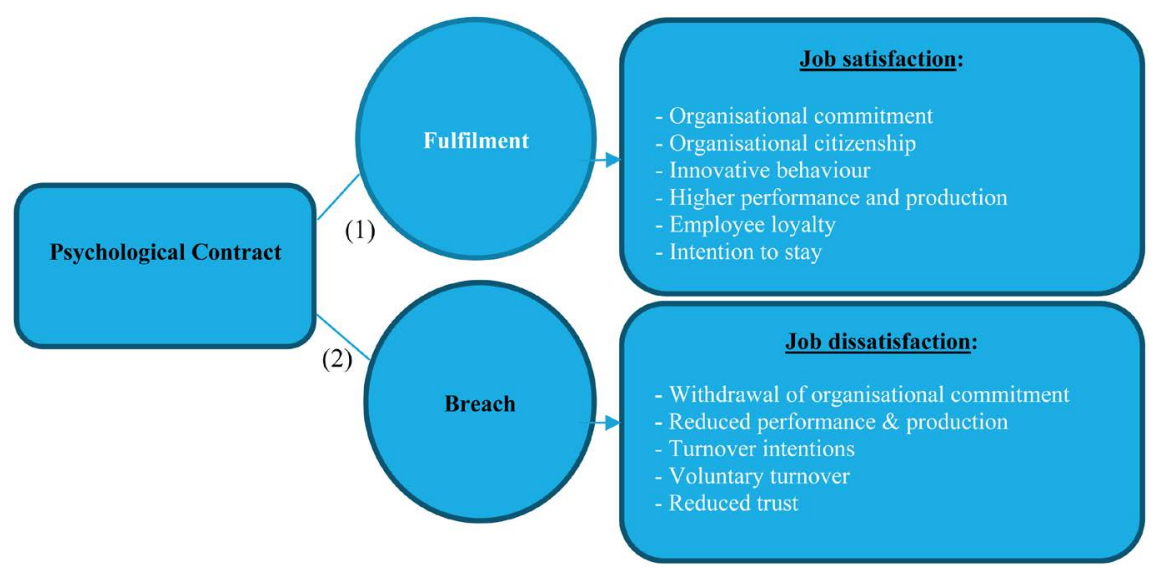

Figure 1. Double-routed impact of psychological contract on job satisfaction and dissatisfaction. Source: researchers' derivation based on reviewed literature.

breached the contract (Coyle-Shapiro \& Parzefall, 2008). Maimane et al. (2018) and Zacher and Rudolph (2021) state that psychological contract breach takes place when employees become convinced that their employers has failed to meet one or more of their obligationg as expected in terms of the terms of their psychological contract. Just like it has been revealed in the definition provided by Coyle-Shapiro \& Parzefall (2008), when employees perceive a breach on their psychological contract, they feel violated and experience emotions of anger, betrayal, frustration, anxiety, and resentment over their employers (Maimane et al., 2018).

Employees react negatively when they feel that the terms of their psychological contract have been breached, to such an extent that they would not hesitate to retaliate by reducing their performance efforts and withdrawing their organisational commitment, which oviously negatively affect production in organisations (Maimane et al., 2018; Liu, 2019). Gallani et al. (2019) state that psychological contract breach leads to perceptions of fairness violation among employees, and ultimately results in punitive response behaviours aimed at retaliating against the employer's perceived unfair treatment towards them. Studies have found that such retaliations may include negative outcomes such as reduced job performance, intention to leave, job dissatisfaction, withdrawn organisational commitment, decreased trust (Herrera \& Las Heras-Rosas, 2021). Areas of focus that have been found to be where breaches are mostly perceived include those such as among others, salary, promotion, career development and job security (Maimane et al., 2018). This notion is confirmed by Herrera and Las Heras-Rosas (2021) who further add that in most instances psychological contract breach is triggered by restructuring and downsizing of organisations which are always misunderstood as indications of the employers' breach of their employees' psychological contract. Liu (2019) reveals that employees' reaction to a breach will be very severe when employees are convinved that their employers have deliberately ignored to fulfil their obligations and/or intentionally reneged from keeping their promises. Hence the psychological contract breach has been 
found to be negatively related to favourable job attitudes and performance in organisations, which make employees even more likely to be doubtful of their future aspirations because of the unpredictable behaviours of their employers (Zacher \& Rudolph, 2021).

Two earlier empirical studies have revealed detailed findings about the impact of psychological contract breach in workplace relationships. Firstly, the study by Winter and Jackson (2006) found that employees who perceived a breach of their psychological contract, reduced their commitment and were not willing to engage in positive organisational citizenship behaviour. The second study by Coyle-Shapiro and Parzefall (2008) reiterated that empirical evidence reveals that a breach of the psychological contract result in reduced psychological well-being, job dissatisfaction, mistrust, withdrawn organisational commitment, increased intentions to leave the organisation, and negative attitudes towards the organisation. Cregan et al. (2021) agree with the authors and further reveal that the psychological contract theory predicts that when employees feel that their psychological contract has been breached, they retaliate by reducing their contribution and effort in the organisation which always has very negative effcts in its continued survival.

Any perception of breach of their psychological contract always leave the employees in a state of dissatisfaction about their work and even about the organisation itself (Coyle-Shapiro \& Parzefall, 2008). Employees' job dissatisfaction arising from psychological contract breach results in employees' negative attitude and destructive behaviours, which are obviously detrimental to the survival of organisations (Herrera \& Las Heras-Rosas, 2021). The impact of psychological contract breach on job dissatisfaction is displayed on route (2) of Figure 1.

\section{Determinants of Employees' Job Satisfaction}

A study by Sowmya and Panchanatham (2011) has revealed that there are factors which have been identified as determinants of job satisfaction known as recognition and appreciation, co-workers, supervision, job conditions, policies and procedures, fringe benefits, nature of the organisation, compensation, promotion opportunities, and job security. These factors have been depicted in Figure 2 below, and are discussed in this section. It however, has to be noted that the determinants listed below in Figure 2, should not be seen as the only determinants as there are also other determinants which will have a significant influence on job satisfaction in the workplace.

\subsection{Recognition and Appreciation}

Jehanzeb et al. (2012) reveal that studies have identified non-monetary compensation as one of the most important motivators in the workplace. This notion is supported by Ntimba (2019) who confirm that appreciation other than monetary rewards which employees may from time to time receive is of cardinal importance, as employees also expect to be valued for the good work they do in the workplace. A study conducted by Jehanzeb et al. (2012) found that employees 


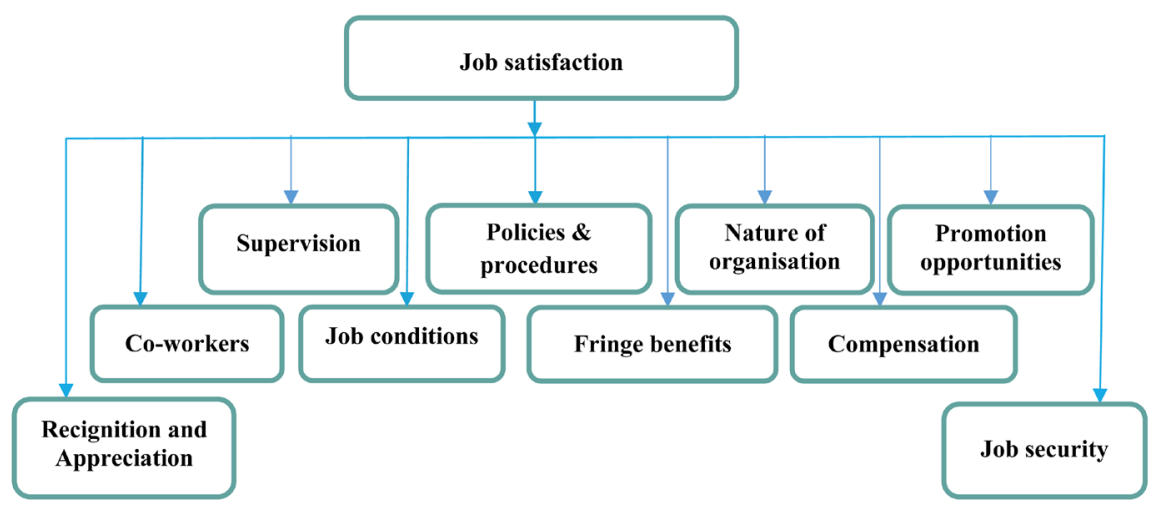

Figure 2. Determinants of job satisfaction. Source: researchers' derivation based on reviewed literature.

who receive recognition become closer with their organisations and perform even better. This is true, in view of the fact that recognition and rewards have been found to increase employees' levels of efficiency and performance.

\subsection{Co-Workers}

The employee-employee relationship, refers to the relationship that a worker has with his co-workers. An earlier study conducted by Curseu et al. (2008) revealed that the relationship which employees develop from within workgroups arises from their eagerness to interact with one another. This relationship has a direct influence on the performance of their tasks in the workplace. This finding was supported by subsequent research study conducted by Flanagan and Runde (2009), which found that all disagreements among workgroup members have the potential of devolving into relationship conflict. Shah (2017) states that distress and ineffective working environment are outcomes of a conflict situation where misunderstandings and negative relationships are rife in the workplace. As a result, organisations should at all times strive towards the creation of an environment in which employees support and assist one another in their challenging jobs in the workplace.

\subsection{Supervision/Leadership Behaviour}

The way a supervisor relates to his subordinate employees is of significance as it will determine whether or not the employees will be satisfied with their jobs in the workplace (Ntimba, 2019). A relationship has been found between learship behaviour and employee satisfaction in the workplace (Bhardwaj, Mishra, \& Jain, 2021). In support of this notion, Sudiarta (2021) re-iterates that the presence of good learship in work organisations is a determining factor for employee performance, as production will largely depend on how the supervisor or manager optimally uses the employees.

\subsection{Job Conditions}

Favourable job conditions are very important to employees. The absence of de- 
sirable conditions in the workplace can impact negatively on the employees' mental and physical well-being and subsequently interfere with their performance and ultimately their job satisfaction do (Parvin \& Kabir, 2011). Employees want to work in an environment that is motivating in terms of conditions, which includes guaranteed safety with regard to the work being done in the organisation. The more comfortable employees are in the workplace, the more productive they will be (Sageer et al., 2012). This notion is supported by Suffian et al. (2018), who state that working conditions will affect the satisfaction of employees in the workplace because employees want to work in an environment where they feel comfortable with their physical surroundings.

\subsection{Policies and Procedures}

Policies and procedures that consider and treat employees as valuable members of the organisations are more likely to produce satisfied employees who will be more likely to do their work to customers' satisfaction and also be more productive (Huang \& Rundle-Thiele, 2014). Djukic et al. (2017) further add that fair organisational policies and procedures ensure that employees' satisfaction with their jobs will not be affected, even where employees are faced with high stressful job demands. This is true if they have a positive perception with regard to prevailing organisational justice and if they are treated fairly and are given a voice in the decision-making (Djukic et al., 2017).

\subsection{Fringe Benefits}

Fringe benefits have also been found to play a significant role in determining whether or not employees will be satisfied in the workplace. One needs to always bear in mind that job satisfaction does not depend on the nature of the job only, but also on the employee's expectations regarding what the job is expected to provide to the employee in terms of benefits (Parvin \& Kabir, 2011). Therefore, job satisfaction should not be understood to mean only a situation where the employee is happy with their job, but also includes the employee's expectations with regard to what the employee expects the job to provide (Ramoo et al., 2013). Sharma and Jaiswal (2018) state that fringe benefits also serve as indirect compensation to employees.

\subsection{Nature of the Organisation}

Studies have found that organisations that embrace job satisfaction in their workplaces are able to achieve their set goals, retain their quality employees and attract the type of employees who have the required skills (Voon et al., 2011). This notion is further confirmed by Mohammad et al. (2011), who reveal that further studies have found that there is a relationship between job satisfaction and employees' physical and mental well-being. This relationship has an influence on their job-related behaviour in the workplace, which determine how they relate to their organisation. Holman, Johnson and O'Connor (2018) reiterate 
that activities that organisations use for the improvement of employee well-being and reduction of the impact of stress on employees, also play an important role in the workplace. This notion is supported by Das et al. (2018: p. 1), who further state that employer-based well-being initiatives are of utmost importance as they have a potential to "positively influence physical and psychological health" of the employees in the workplace.

\subsection{Compensation}

According to Mahalawat and Sharma (2019) compensation can be defined as an amount of reward that employees receive for their contribution or work done. Gürlek (2020) reveals that employees start to experience dissatisfaction with their pay as soon as they start to compare the quantity of the work they do for their employers, with the pay they receive as compensation for their labour. A study by Bao, Cheng and Smith (2020) found a direct link between pay equity and job satisfaction and between pay equity and employee performance in organisations. Vuong et al. (2021) state that employees begin to be satisfied when they feel that they receive the compensations that is equivalent to the contributions they make to the organisation. This view is supported by Sudiarta (2021) who further states that the amount of salary that an employee receives from the employer always serves as one of the main indicators of job satisfaction.

\subsection{Promotion Opportunities}

Jehanzeb et al. (2012) state that promotion usually depends on performance and is also one of the strongest forms of motivation among employees to work harder in order to be elevated to higher positions. Ramlawati et al. (2021) however, argue that it is not only dissatisfied employees who will think of leaving their current job, but even satisfied employees may become dissatisfied when they discover that there are other jobs in the labour market that can provide them with better opportunities than their current job. This finding by Ramlawati et al. (2021) is consistent with an earlier finding of Gerhart (1990) which found a relationship between employees' job satisfaction and job opportunities in the labour market.

\subsection{Job Security}

Employees want to have security about their job, meaning that they want assurance that they will still have their current job even in future. Where such job security is not guaranteed, employees become worried about their future in the organisation (Sageer et al., 2012; Mahalawat \& Sharma, 2019). According to Jung, Jung and Yoon (2021), job insecurity takes place when employees become afraid for a possibility of losing their jobs and become unemployed. When an employee experiences this fear, his/her psychological health is also affected, which obviously has a negative impact on the employee's performance and engagement with other fellow employees in the workplace. 


\section{Consequences of Employees' Job Dissatisfaction}

It has been confirmed by studies that job dissatisfaction is a consequence of certain factors (Winter \& Jackson, 2006; Coyle-Shapiro \& Parzefall, 2008; Cregan et al., 2021; Liu, 2019; Herrera \& Las Heras-Rosas, 2021). The factors listed and discussed below are outcomes of job dissatisfaction:

\subsection{Withdrawal of Organisational Commitment}

Numerous studies which investigated whether there is any relationship between organisational commitment and job satisfaction, have concluded that there is a significant relationship between the two constructs, with a correlational nature (Yousef, 2017). When employees are dissatisfied in the workplace they withdraw their commitment to the organisational, which is usually displayed by reducing their contribution and effort in the organisation. This has always proved to have very negative effects on the organisations' continued survival (Cregan et al., 2021).

\subsection{Reduced Performance and Production}

Nwobia and Aljohani (2017) state that job dissatisfaction affects employees' performance directly with the result that it ends up triggering their low morale and intention to leave the organisation. Employees' dissatisfaction in the workplace leads to employees deliberately reducing their job performance with an aim of reducing the production, as a sign of retaliation against their employer's actions which they have found unacceptable (Zacher \& Rudolph, 2021).

\subsection{Turnover Intentions}

Intention to leave arises from an employee's subjective evaluation of the organisation that results in their decision to leave the organisation, based on the dissatisfaction experienced by the employee (Ntimba, 2019). Ramlawati et al. (2021: p. 512) define turnover as "the process by which employees leave the organisation and must be replaced immediately". This is one of the main areas which results is serious loss to organisations in terms of lost skilled employees, cost of recruiting and training of newly appointed employees, and production lost during the training and recruitment process.

\subsection{Voluntary Turnover}

Nwobia and Aljohani (2017) state that when skilled employees leave organisations, the ability of remaining employees to complete their allocated tasks is also affected. In organisations where skilled employees are resigning in large numbers, management will be expected to recruit new skilled employees to replace all those who have left. This is usually a costly exercise for organisations as it also affects production time lost during the recruitment and development process of newly appointed employees (Ramlawati et al., 2021). 


\subsection{Reduced Trust}

When something has happened in the workplace which results in employees' dissatisfaction, employees will always react by, among other tactics of retaliation, withdrawing their trust over their employer to show their anger and frustration over the unacceptable action of their employer (Coyle-Shapiro \& Parzefall, 2008; Maimane et al., 2018). A broken trust can have very destructive effects on organisations as employees will always be demotivated in giving their best in the workplace (Supriyanto, Ekowati, \& Maghfuroh, 2020). Where employees perceive their employer as having breached their trust, they become more likely to be even doubtful of their future aspirations because of their employer's unpredictable behaviours (Zacher \& Rudolph, 2021).

\section{Recommended Strategies of Improving Job Satisfaction in Organisations}

Job satisfaction is a vital factor in any organisation, as the attitudes of employees reflect the moral of the organisation. The positive attitude of employees, however, depends on how happy or satisfied they are in the workplace, which places a huge responsibility on work organisations to ensure that the satisfaction of employees is always promoted in the workplace. It is for that reason therefore, that this study has compiled the following management strategies which leadership and management of organisations can use to promote the fulfilment of the psychological contract and thereby improve job satisfaction in the workplace:

- To avoid experiencing challenges arising from management's poor performance with regard to open communication transparency and management skill, organisations shall have to empower their managements with the necessary skills. This therefore, means that the achievement of psychological contract fulfilment will require skills that will ensure that employees and employers are adequately empowered in ensuring effective psychological contract fulfilment towards each other (Arthur \& Kolson, 2017).

- To maintain a healthy relationship among employees and boost performance, it is necessary that employers should encourage their employees to have trust in the organisations as that is a necessity for the organisations' continued survival (Liu, 2019).

- To ensure the development and maintenance of an effective psychological contract between management and employees, organisations should invest more on building mutual trust as that will lead to the satisfaction of employees in the workplace (Niehof \& Paul, 2001).

- To promote employees' satisfaction in organisations, managements need to promote the sharing of information with their employees and also listen to what they have to say in response, rather than arrogantly adhering to their one-way type of communication which erodes employees' obedience and loyalty in organisation (Phuong \& Tkahashi, 2021).

- To avoid negative consequences in organisations, management should always provide an explanation where the obligations have not been fulfilled and 
where possible, provide alternative options and resources for employees to cope with the perceived breach (Zacher \& Rudolph, 2021).

- To keep employees' behaviour within positive parameters which give rise to trust, loyalty and satisfaction, organisations have to promote projects that will result in mutual benefit and also always try to satisfy the demands of employees. This is of importance, as loyal employees will always stand by the organisation even in times of difficulties especially where other employees would have chosen to flee in distress (Vuong et al., 2021).

- To boost production in the workplace, managers in organisation should always strive towards keeping their employee happy as it is believed that an employee is considered productive when he is happy (Bhardwaj, Mishra, \& Jain, 2021).

The biggest challenge that organisations seem to be faced with is to ensure that their employees are satisfied in the workplace. However, keeping employees happy and/or satisfied in the workplace is not an easy task although it has many benefits, without which organisations cannot survive (Dabos \& Rousseau, 2004; Aggarwal \& Bhargava, 2009; Dhanpat \& Parumasur, 2014; Tekleab et al., 2020). Hence management and leadership of organisations have to work tirelessly to ensure that all concerns of employees are addressed timeously in order to avoid any misunderstanding that could result in innocent omissions of employers being erroneously interpreted as breach of their psychological contract.

\section{Conclusion}

The study examined the influence that the psychological contract has on job satisfaction and dissatisfaction of employees in the South African workplace. The study found that there is a positive relationship between psychological contract fulfilment and job satisfaction, while a negative relationship was found between psychological contract breach and job satisfaction. This led the authors of this article to the conclusion that, in workplaces where the psychological contract has been fulfilled, employees will be satisfied with their job, while in workplaces where the psychological contract has been breached, employees will be dissatisfied with their job. As a result, if organisations intend to improve their employees' job satisfaction in the workplace, they should invest more in empowering their leaders and managers with knowledge and skills relating to the psychological contract in general, and psychological contract fulfilment and breach in particular. Focal areas for such empowerment have been mentioned in this article in order to assist them in the identification of areas to which the training and development should pay attention. This study therefore, plays a very important and significant role in terms of contributing to literature and a better understanding of psychological contract, as well as the effects that it has on employees' job satisfaction and dissatisfaction in the workplace.

\section{Conflicts of Interest}

The authors declare no conflicts of interest regarding the publication of this paper. 


\section{References}

Aggarwal, U., \& Bhargava, S. (2009). Reviewing the Relationship between Human Resource Practices and Psychological Contract and Their Impact on Employee Attitude and Behaviours: A Conceptual Model. Journal of European Industrial Training, 33, 4-31. https://doi.org/10.1108/03090590910924351

Arthur, J. L., \& Kolson, M. F. (2017). Psychological Contract Fulfillment and Its Implication on Performance of Employees: The Case of Asanko Gold Mine, Ghana. Journal of Public Administration and Policy Research, 9, 17-25. https://doi.org/10.5897/JPAPR2017.0402

Bao, M. X., Cheng, X., \& Smith, D. (2020). A Path Analysis Investigation of the Relationships between CEO Pay Ratios and Firm Performance Mediated by Employee Satisfaction. Advances in Accounting, 48, Article ID: 100457. https://doi.org/10.1016/j.adiac.2020.100457

Bhardwaj, A., Mishra, S., \& Jain, T. K. (2021). An Analysis to Understanding the Job Satisfaction of Employees in Banking Industry. Materials Today: Proceedings, 37, 170-174. https://doi.org/10.1016/j.matpr.2020.04.783

Collins, A., \& Beauregard, A. (2020). The Effect of Breaches of the Psychological Contract on the Job Satisfaction and Wellbeing of Doctors in Ireland: A Quantitative Study. $\mathrm{Hu}$ man Resources for Health, 18, Article No. 89. https://doi.org/10.1186/s12960-020-00534-3

Coyle-Shapiro, J., \& Parzefall, M. (2008). Psychological Contracts. In C. L. Cooper, \& J. Barling (Eds.), The Sage Handbook of Organisational Behaviour (pp. 17-34). Sage. https://doi.org/10.4135/9781849200448.n2

Cregan, C., Kulik, C. T., Metz, I., \& Brown, M. (2021). Benefit of the Doubt: The Buffering Influence of Normative Contracts on the Breach-Workplace Performance Relationship. The International Journal of Human Resource Management, 32, 1390-1417. https://doi.org/10.1080/09585192.2018.1528471

Curseu, P. L., Kenis, P., \& Raab, J. (2008). Reciprocated Relational Preferences and Intra-Team Conflict. Team Performance Management, 15, 18-34. https://doi.org/10.1108/13527590910937694

Dabos, G. E., \& Rousseau, D. M. (2004). Mutuality and Reciprocity in the Psychological Contracts of Employees and Employers. Journal of Applied Psychology, 89, 52-64. https://doi.org/10.1037/0021-9010.89.1.52

Danial, M., \& Nasir, Q. A. (2020). Effect of Psychological Contract on Employee's Performance with Employee Engagement as Mediator. Journal of Research in Psychology, 2, 24-34.

Das, S. K., Mason, S. T., Vail, T. A., Rogers, G. V., Livingston, K. A., Whelan, J. G., Chin, M. K., Blanchard, C. M., Turgiss, J. L., \& Roberts, S. B. (2018). Effectiveness of an Energy Management Training Course on Employee Well-Being: A Randomized Controlled Trial. American Journal of Health Promotion, 33, 118-130. https://doi.org/10.1177/0890117118776875

De Clercq, D., Azeem, M. U., \& Haq, I. U. (2021). But They Promised! How Psychological Contracts Influence the Impact of Felt Violations on Job-Related Anxiety and Performance. Personnel Review, 50, 648-666. https://doi.org/10.1108/PR-07-2019-0388

Dhanpat, N., \& Parumasur, S. B. (2014). Re-Establishing the Psychological Contract as a Precursor to Employee Retention. Problems and Perspectives in Management, 12, 78-90.

Djoemadi, F. R., Setiawan, M., Noermijati, N., \& Irawanto, D. W. (2019). The Effect of 
Work Satisfaction on Employee Engagement. Polish Journal of Management Studies, 19, 101-111. https://doi.org/10.17512/pjms.2019.19.2.08

Djukic, M., Jun, J., Kovner, C., Brewer, C., \& Fletcher, J. (2017). Determinants of Job Satisfaction for Novice Nurse Managers Employed in Hospitals. Health Care Management Review, 42, 172-183. https://doi.org/10.1097/HMR.0000000000000102

Flanagan, T., \& Runde, C. (2009). How Teams Can Capitalize on Conflict. Strategy and Leadership, 37, 20-22. https://doi.org/10.1108/10878570910926025

Gallani, S., Krishnan, R., Marinich, E., \& Shields, M. D. (2019) Budgeting, Psychological Contracts, and Budgetary Misreporting. Management Science, 65, 2924-2945. https://doi.org/10.1287/mnsc.2018.3067

Gerhart, B. (1990). Voluntary Turnover and Alternative Job Opportunities. Journal of Applied Psychology, 75, 467-476. https://doi.org/10.1037/0021-9010.75.5.467

Giauque, D., Ritz, A., Varone, F., \& Anderfuhren-Biget, S. (2012). Resigned but Satisfied: The Negative Impact of Public Service Motivation and Red Tape on Work Satisfaction. Public Administration, 90, 175-193. https://doi.org/10.1111/j.1467-9299.2011.01953.x

Griep, Y., \& Vantilborgh, T. (2018). Reciprocal Effects of Psychological Contract Breach on Counterproductive and Organisational Citizenship Behaviours: The Role of Time. Journal of Vocational Behaviour, 104, 141-153. https://doi.org/10.1016/j.jvb.2017.10.013

Gürlek, M. (2020). How Does Work Overload Affect Unethical Behaviors? The Mediating Role of Pay Dissatisfaction. Turkish Journal of Business Ethics, 17-26.

Herrera, J., \& Las Heras-Rosas, D. (2021). The Organisational Commitment in the Company and Its Relationship with the Psychological Contract. Frontiers in Psychology, 11, Article ID: 609211. https://doi.org/10.3389/fpsyg.2020.609211

Holman, D., Johnson, S., \& O’Connor, E. (2018). Stress Management Interventions: Improving Subjective Psychological Well-Being in the Workplace. In E. Diener, S. Oishi, \& L. Tay (Eds.), Handbook of Well-Being. DEF Publishers.

Huang, Y. T., \& Rundle-Thiele, S. (2014). The Moderating EFFECT of Cultural Congruence on the Internal Marketing Practice and Employee Satisfaction Relationship: An Empirical Examination of Australian and Taiwanese Born Tourism Employees. Tourism Management, 42, 196-206. https://doi.org/10.1016/j.tourman.2013.12.005

Janssen, O. (2001). Fairness Perceptions as a Moderator in the Curvilinear Relationships between Job Demands, and Job Performance and Job Satisfaction. Academy of Management Journal, 44, 1039-1050. https://doi.org/10.2307/3069447

Jehanzeb, K., Rasheed, M. F., \& Rasheed, A. (2012). Impact of Rewards and Motivation on Job Satisfaction in Banking Sector of Saudi Arabia. International Journal of Business and Social Science, 3, 272-278.

Jung, H. S., Jung, Y. S., \& Yoon, H. H. (2021). COVID-19: The Effects of Job Insecurity on the Job Engagement and Turnover Intent of Deluxe Hotel Employees and the Moderating Role of Generational Characteristics. International Journal of Hospitality Management, 92, Article ID: 102703. https://doi.org/10.1016/j.ijhm.2020.102703

Lambert, L. S., Edwards, J. R., \& Cable, D. M. (2003). Breach and Fulfilment of the Psychological Contract: A Comparison of Traditional and Expanded Views. Personnel Psychology, 56, 895-934. https://doi.org/10.1111/j.1744-6570.2003.tb00244.x

Liu, Z. (2019). Impact of Psychological Contract Fulfillment on Micro-Firm Clerks: An Empirical Study in China. African Journal of Business Management, 13, 343-352. https://doi.org/10.5897/AJBM2019.8759

Mahalawat, V., \& Sharma, B. (2019). Study of Factors Affecting Employee Satisfaction 
and Their Impact on the Organisation. Journal of Xi'an University of Architecture \& Technology, 11, 939-945.

Maimane, K., Motilall, A., Ngqeza, K., Thompson, S., \& Chrysler-Fox, P. (2018). The Impact of Psychological Contract Breach and Violation on Union Commitment. 35th Annual Pan-Pacific Conference, Seoul, Korea, 58-60.

Mohammad, J., Quoquab Habib, F., \& Alias, M. A. (2011). Job Satisfaction and Organisational Citizenship Behaviour: An Empirical Study at Higher Learning Institutions. Asian Academy of Management Journal, 16, 149-165.

Morf, M., Arnold, A., \& Staffelbach, B. (2014). The Double Psychological Contracts of Temporary Agency Workers. Employee Relations, 36, 708-726. https://doi.org/10.1108/ER-03-2013-0026

Morsch, J., van Dijk, D., \& Kodden, B. (2020). The Impact of Perceived Psychological Contract Breach, Abusive Supervision, and Silence on Employee Well-Being. Journal of Applied Business and Economics, 22, 37-53. https://doi.org/10.33423/jabe.v22i2.2799

Niehof, B. P., \& Paul, R. J. (2001). The Just Workplace: Developing and Maintaining Effective Psychological Contracts. Review of Business, 22, 5-26.

Ntimba, D. I. (2019). A Framework for Managing Employment Relations through Employment Relations Satisfaction and Psychological Contracts in Selected Government Departments. Doctoral Thesis, Tshwane University of Technology. (Unpublished)

Nwobia, I. E., \& Aljohani, M. S. (2017). The Effect of Job Dissatisfaction and Workplace Bullying on Turnover Intention: Organisation Climate and Group Cohesion as Moderators. International Journal of Marketing Studies, 9, 136-143. https://doi.org/10.5539/ijms.v9n3p136

Othman, N., Mokhtar, S. S. M., \& Asaad, M. N. M. (2017). Quality Management System, Employee Satisfaction and Employee Performance in Private Higher Education Institutions: A Proposed Framework. International Journal of Management Research and Reviews, 7, 681-686.

Parvin, M. M., \& Kabir, M. N. (2011). Factors Affecting Employee Job Satisfaction of Pharmaceutical Sector. Australian Journal of Business and Management Research, 1, 113-123.

Persson, S., \& Wasieleski, D. (2015). The Seasons of the Psychological Contract: Overcoming the Silent Transformations of the Employer-Employee Relationship. Human Resource Management Review, 25, 368-383. https://doi.org/10.1016/j.hrmr.2015.02.003

Phuong, T. H \& Takahashi, K. (2021). The Impact of Authentic Leadership on Employee Creativity in Vietnam: A Mediating Effect of Psychological Contract and Moderating Effects of Subcultures. Asia Pacific Business Review, 27, 77-100. https://doi.org/10.1080/13602381.2021.1847467

Ramlawati, R., Trisnawati, E., Yasin, N., \& Kurniawaty, K. (2021). External Alternatives, Job Stress on Job Satisfaction and Employee Turnover Intention. Management Science Letters, 11, 511-518. https://doi.org/10.5267/j.msl.2020.9.016

Ramoo, V., Abdullah, K. L., \& Piaw, C. Y. (2013). The Relationship between Job Satisfaction and Intention to Leave Current Employment among Registered Nurses in a Teaching Hospital in Malaysia. Journal of Clinical Nursing, 22, 3141-3152. https://doi.org/10.1111/jocn.12260

Rousseau, D. M. (1995). Psychological Contracts in Organisations. Sage.

Rousseau, D. M., \& Tijoriwala, S. (1998). Assessing Psychological Contracts: Issues, Alternative and Measures. Journal of Organisational Behaviour, 19, 679-695. https://doi.org/10.1002/(SICI)1099-1379(1998)19:1+<679::AID-JOB971>3.0.CO;2-N 
Sageer, A., Rafat, S., \& Agarwal, P. (2012). Identification of Variables Affecting Employee Satisfaction and Their Impact on the Organisation. IOSR Journal of Business and Management, 5, 32-39. https://doi.org/10.9790/487X-0513239

Shah, M. (2017). Impact of Interpersonal Conflict in Health Care Setting on Patient Care; The Role of Nursing Leadership Style on Resolving the Conflict. Nurse Care Open Access Journal, 2, 44-46. https://doi.org/10.15406/ncoaj.2017.02.00031

Sharma, K., \& Jaiswal, N. (2018). A Study on Employees' Attitude towards Fringe Benefits. International Journal of Engineering and Management Research (IJEMR), 8, 176-180. https://doi.org/10.31033/ijemr.v8i02.11649

Silitonga, N., Novitasari, D., Sutardi, D., Sopa, A., Asbari, M., Yulia, Y., Supono, J., \& Fauji, A. (2020). The Relationship of Transformational Leadership, Organisational Justice and Organisational Commitment: A Mediation Effect of Job Satisfaction. Journal of Critical Reviews, 7, 89-108.

Sowmya, K. R., \& Panchanatham, N. (2011). Factors Influencing Job Satisfaction of Banking Sector Employees in Chennai, India. Journal of Law and Conflict Resolution, 3, 76-79.

Sudiarta, C. (2021). Factors Affecting Employee Performance of Education Office in Tabanan Regency. Journal of Humanities, Social Science, Public Administration and Management (HUSOCPUMENT), 1, 52-59.

https://doi.org/10.51715/husocpument.v1i2.59

Suffian, M. Z. A., Rohani, M., \& Mariam, R. B. R. (2018). Employee Satisfaction among Administration Staff: A Case Study at Eastern Pacific Industrial Corporation Berhad, Terengganu, Malaysia. Journal of Fundamental and Applied Sciences, 10, 673-687.

Supriyanto, A., Ekowati, V., \& Maghfuroh, U. (2020). Do Organisational Citizenship Behavior and Work Satisfaction Mediate the Relationship between Spiritual Leadership and Employee Performance? Management Science Letters, 10, 1107-1114. https://doi.org/10.5267/j.msl.2019.10.031

Tekleab, A. G., Laulié, L., De Vos, A., De Jong, J. P., \& Coyle-Shapiro, J. A. (2020). Contextualizing Psychological Contracts Research: A Multi-Sample Study of Shared Individual Psychological Contract Fulfilment. European Journal of Work and Organisational Psychology, 29, 279-293. https://doi.org/10.1080/1359432X.2019.1608294

Van der Walt, F., Thasi, M. E., Chipunza, C., \& Jonck, P. (2016). Skills Shortages and Job Satisfaction-Insights from the Gold-Mining Sector of South Africa. African Journal of Business and Economic Research, 11, 143-183.

Varma, C., \& Chavan, C. (2020). The Effect of Perceived Organisational Support and Psychological Contract on Employee Job Satisfaction and Turnover Intention. Journal of the Social Science, 48, 1458-1473.

Voon, M. L., Lo, M. C., Ngui, K. S., \& Ayob, N. B. (2011). The Influence of Leadership Styles on Employees' Job Satisfaction in Public Sector Organisations in Malaysia. International Journal of Business, Management and Social Sciences, 2, 24-32.

Vuong, B., Tung, D., Tushar, H., Quan, T., \& Giao, H. (2021). Determinates of Factors Influencing Job Satisfaction and Organisational Loyalty. Management Science Letters, 11, 203-212. https://doi.org/10.5267/j.msl.2020.8.014

Winter, R., \& Jackson, B. (2006). State of the Psychological Contract: Manager and Employee Perspectives within an Australian Credit Union. Employee Relations, 28, 421-434. https://doi.org/10.1108/01425450610683636

Yousef, D. A. (2017). Organisational Commitment, Job Satisfaction and Attitudes toward Organisational Change: A Study in the Local Government. International Journal of Pub- 
D. I. Ntimba et al.

lic Administration, 40, 77-88. https://doi.org/10.1080/01900692.2015.1072217

Zacher, H., \& Rudolph, C. W. (2021). Relationships between Psychological Contract Breach and Employee Well-Being and Career-Related Behavior: The Role of Occupational Future Time Perspective. Journal of Organisational Behavior, 42, 84-99.

https://doi.org/10.1002/job.2495 